\title{
NANNOFOSSIL BIOSTRATIGRAPHY OF THE UPPER SANTA ANITA AND LOWER MERECURE GROUPS, RIO ARAGUA, EASTERN VENEZUELA
}

\author{
LUNA*, Flor C., PILLOUD, Andres, CRUX Jason A., FARIAS, Arelis, Earth
} Science Departament, INTEVEP, S.A., Apdo 76343, Caracas 1070A, Venezuela; CASTRO, Marianto, LAGOVEN, S.A., Caracas, Venezuela.

The upper Santa Anita and lower Merecure groups are exposed along the Aragua river in northeastern Venezuela, near the San Francisco strike-slip fault. They reflect the transition of this part of the northern margin of South America from a passive margin to an active foreland basin. Up-dip from these exposures these groups provide the reservoirs of the El Furrial trend and other thurst related oil fields. The section has been lithostratigraphically and biostratigraphically studied for foraminifera as early as the 1960 's, but this is the first attempt to systematically examine the nannofossils.

The section was completely remeasured and described during the bed by bed sampling. The section is structurally complex wiht numerous faults and exposure is not complete. This leads to some stractigraphic gaps and parallel overlapping section, which complicates the interpretations of results.

The section extends from the late Maastrichtian (NC21?) to the Oligocene (NP25).The absence of NP5 to NP8 strata is either due to a gap in the exposure or a real hiatus in sedimentation. A similar gap also occur in NP15 which may be due to poor exposure or barren condensed sediments. An apparent hiatus between NP20 and NP22 is probably due to submarine erosion and condensing of the sediments in glauconitic rich horizons barren of nannofossils.

The nannofossil biostratigraphy in combination with sedimentologic studies leads to a sequence interpretation. The sequences are compared with those proposed by Haq and his co-workers for passive margins to see what influence the tectonic events have had on the sedimentary record. 